\title{
Anxiety and food behavior in nutrition students
}

\author{
Ansiedade e comportamento alimentar em estudantes de nutrição \\ Ansiedad y conducta alimentaria en estudiantes de nutrición
}

Received: 01/30/2022 | Reviewed: 02/03/2022 | Accept: 02/06/2022 | Published: 02/12/2022

\author{
Karine Dorn da Silva Rech Pinto \\ ORCID: https://orcid.org/0000-0003-4729-669X \\ Centro Universitário de Volta Redonda, Brasil \\ E-mail: kdornrech@hotmail.com \\ Bruna Casiraghi \\ ORCID: https://orcid.org/0000-0001-8114-3772 \\ Centro Universitário de Volta Redonda, Brasil \\ E-mail: bruna.casiraghi@foa.org.br \\ Júlio César Soares Aragão \\ ORCID: https://orcid.org/0000-0002-8210-6348 \\ Centro Universitário de Volta Redonda, Brasil \\ E-mail: bruna.casiraghi@foa.org.br
}

\begin{abstract}
Introduction: The last century pointed out a significant rise an anxiety for the human population as a response to social cultural and economic scenario changes. The university years are characterized by positive experiences and also by stressful factors, which may result in increased anxiety and changes in eating habits. Objectives: This study aimed to identify the correlation between anxiety and eating behavior of university students, examining how anxiety impacts nutrition students' eating habits. Methods and materials: Data concerning 158 from freshman to senior year nutrition course students were evaluated, consisting of 141 women and 17 men, with an average age of 22,6. This study used validated instruments to measure these constructs: a survey on anxiety (IDATE); another one on eating behavior (TFEQ-21), and basic socioeconomic data of the students participating in the survey. Results: Positive and significant correlation was observed between level of anxiety through STAI-T and the emotional feeding behavior $(\mathrm{p}=0.000)$. It was also seen a positive correlation between the score of the uncontrolled eating behavior $(\mathrm{p}=0.001)$. For cognitive restriction, there was no correlation $(\mathrm{p}=0.672)$. Conclusion: There is a positive correlation between anxiety and eating habits concerning emotional eating. New studies may provide relevant information if expanded to larger populations to gain an assessment of how data behave, including with health professionals in general.
\end{abstract}

Keywords: Anxiety; Feeding behavior; Student health.

\section{Resumo}

Introdução: O último século apontou para um aumento significativo da ansiedade para a população humana como resposta às mudanças do cenário sócio-cultural e econômico. Os anos universitários são caracterizados por experiências positivas e também por fatores estressantes, que podem resultar em aumento da ansiedade e mudanças nos hábitos alimentares. Objetivos: Este estudo teve como objetivo identificar a correlação entre ansiedade e comportamento alimentar de estudantes universitários, examinando como a ansiedade impacta os hábitos alimentares de estudantes de nutrição. Métodos e materiais: Foram avaliados dados de 158 alunos do primeiro ao último ano do curso de nutrição, sendo 141 mulheres e 17 homens, com média de idade de 22,6 anos. Este estudo utilizou instrumentos validados para mensurar esses construtos: inquérito sobre ansiedade (IDATE); outro sobre comportamento alimentar (TFEQ-21) e dados socioeconômicos básicos dos alunos participantes da pesquisa. Resultados: Observou-se correlação positiva e significativa entre o nível de ansiedade por meio do STAI-T e o comportamento alimentar emocional $(\mathrm{p}=0,000)$. Também foi observada uma correlação positiva entre o escore do comportamento alimentar não controlado $(\mathrm{p}=0,001)$. Para restrição cognitiva, não houve correlação $(\mathrm{p}=0,672)$. Conclusão: Existe uma correlação positiva entre ansiedade e hábitos alimentares relacionados à alimentação emocional. Novos estudos podem fornecer informações relevantes se expandidos para populações maiores para obter uma avaliação de como os dados se comportam, inclusive com profissionais de saúde em geral.

Palavras-chave: Ansiedade; Comportamento alimentar; Saúde do estudante.

\section{Resumen}

Introducción: El último siglo ha señalado un aumento significativo de la ansiedad de la población humana en respuesta a los cambios en el escenario sociocultural y económico. Los años universitarios se caracterizan por experiencias positivas y estresantes, lo que puede resultar en un aumento de la ansiedad y cambios en los hábitos alimentarios. Objetivos: Este estudio tuvo como objetivo identificar la correlación entre la ansiedad y el comportamiento alimentario de los estudiantes universitarios, examinando cómo la ansiedad impacta en los hábitos alimentarios de los estudiantes de nutrición. Métodos y materiales: Se evaluaron datos de 158 estudiantes del primero 
al último año del curso de nutrición, 141 mujeres y 17 hombres, con una edad promedio de 22,6 años. Este estudio utilizó instrumentos validados para medir estos constructos: encuesta de ansiedad (IDATE); otra sobre conducta alimentaria (TFEQ-21) y datos socioeconómicos básicos de los estudiantes participantes en la investigación. Resultados: Se observó una correlación positiva y significativa entre el nivel de ansiedad a través del STAI-T y la conducta alimentaria emocional $(\mathrm{p}=0,000)$. También se observó una correlación positiva entre la puntuación de la conducta alimentaria descontrolada $(\mathrm{p}=0,001)$. Para la restricción cognitiva no hubo correlación $(\mathrm{p}=0,672)$. Conclusión: Existe una correlación positiva entre la ansiedad y los hábitos alimentarios relacionados con el comer emocional. Los nuevos estudios pueden proporcionar información relevante si se amplían a poblaciones más grandes para obtener una evaluación de cómo se comportan los datos, incluso con los profesionales de la salud en general.

Palabras clave: Ansiedad; Conducta alimentaria; Salud del estudiante.

\section{Introduction}

Anxiety is a feeling characterized by fear, tension or discomfort arising from danger prediction, something unknown or unusual. It starts to be pathological when episodes occur in an exacerbated way, disproportionate to stimuli and when it interferes in individuals' daily activities, their quality of life and emotional comfort (Castillo et al., 2000).

Fear and anxiety differ in the presence of a trigger event. Fear has an identifiable source to which the individual specifically reacts. On the other hand, anxiety does not have a clearly defined stimulus, being a dispersed apprehension. Dangers, when distant or close, because anxious perceptions accompanied by multiple behaviours corresponding to each individual. From the moment, misleading emotions occur, causing harm and suffering, it is considered pathological (Corregiari, 2012).

The last century pointed out a significant rise an anxiety for the human population as a response to social cultural and economic scenario changes. This transition required the population to adapt to the new pace of life, enhancing the situation (Ferreira et al., 2009a). The estimated number of people with anxiety disorder in the world is approximately 264 million, representing an increase of $14.1 \%$ since 2005. In Brazil, World Health Organization has registered that anxiety-related disorders affect about $9.3 \%$ of the population, equivalent to 18.657 .943 people (World Health Organization, 2017).

Anxiety has as many definitions as manifestation causes. Briefly, it can be defined as a state of apprehension and tension expressed by feelings of pain, danger, or some special need. It differs from fear as it is a response to a known and defined threat, whereas in anxiety, conversely, circumstances are observed in which the danger is an uncertainty (Brandão, 2005).

Anxiety in higher learning students has been studied as academic life can be an important source of uncertainty and disturbance. These investigations have a significant degree of relevance, since anxiety can trigger symptoms such as tachycardia, dizziness, headache, muscle pain, tingling, sweating, in addition to insomnia, tension, irritability and anguish. This condition may result in wide range of harmful health impacts, as the greater the intensity of symptoms and the high level of anxiety, the greater interference with their functions. (Ferreira et al., 2009a; Kuzujanakis, 2020). In addition, it has a high prevalence of psychological suffering, associated with anguish, as, in addition to the demands of one's personal life, there are pressures experienced while adapting to learning and evaluation process (Aragão et al., 2017; Eisenberg et al., 2007).

Kaufman (2013) reports that there is an intense connection between food and emotion. Most people, just thinking about a food they enjoy, transmits feelings, memories, images, emotions and feelings. Feeding has not only a nutritional and vital importance, providing moments of "immediate pleasure", but ads a function of relief and compensation for negative feelings, such as sadness, anguish, anxiety and fear (Matos \& Ferreira, 2021). Food consumption of is sometimes a way to ease internal conflicts and, as a matter of fact, it is possible to achieve some emotional control through eating, as long as it is not used as a substitute for personal problems and confrontations. Thinking about food most of the day is part of daily habits, yet eating is part of a social interaction, revealing customs, social conditions, psychology, and education.

In this context, Alvarenga et al. (2015) indicates behaviour as a way of conducting, encompassing a set of reactions to living with the environment in which it is inserted, under certain situations. In such a manner, eating behaviour is used to 
express all kinds of constructs in the food field: consumption, eating modus, location, and its relationship with culture, society and with food experience in whole.

There are theories that explain need disproportionate intake from a psychosocial point of view. Eating behaviour can be classified into three dimensions: emotional eating, food restriction and uncontrolled eating. Emotional eating represents the individual's vulnerability to experiencing changes in eating habits resulting from changes in mood or challenging situations, as well as the influence of emotions when choosing food, in the same way that the food consumed can change the emotional state. Food restriction is characterized by a set of rules, restrictions, obligations, and food prohibitions in the quest for weight loss. However, the consequence of a restrictive period is the lack of control and food disinhibition, that is, the imposed self-control is lost, exceeding the intake of foods with high energy value, exposure to foods considered "forbidden" and negative stimuli. The lack of food control is marked by the loss of self-control causing the deliberate consumption of food in the absence or presence of hunger (Natacci et al.,2011).

The relationship of the Nutrition student with food has specificities. As they acquire knowledge throughout the course, in addition to the continuous contact with food and its properties, they present great concern in the field, which arouses an obligation to remain within the strict standards of "self-presentation", considered as an important indicator towards the successful professional (Fiates et al., 2001).

A hostile environment, with exposure to lectures, exams, essays and many other learning activities can contribute to an anxiety generating scenario wich would ultimately be compensated with higher food intake (Chui et al., 2019).

The job market has increasingly needed qualified professionals who are able to develop contemporary attributes. These attributes, such as teamwork, multitasking, and specific knowledge are examples of situations in which professionals from various areas must have to compete for a job vacancy. The level at which they aim to achieve, whether in exact, human or health sciences, has different aspects, but similar paths when it comes to academic training. On this path, as they move towards the degree, students build new habits, make commitments, dedicate time and efforts to a higher education course activity in search of excellence and higher performance (Cruz et al., 2021). This scenario of progress and abrupt changes provides an anxiety generating environment. These changes can interfere with eating behaviour and can, in a way, impair feeding habits. In this perspective, the objective of this study is to identify the correlation between anxiety and eating behaviour of university students.

\section{Methodology}

\section{Participants}

Data collection was carried out in 2019 with students of the Nutrition course at a private university in the municipality of Volta Redonda - Rio de Janeiro State - Brazil by means of an electronic form available online and with no participant identification possibility. The form was composed of 3 parts: personal data; State-Trait Anxiety Inventory - STAI and the Three Factor Eating QuestionnaireTFEQ-R21. Personal data were requested to characterize assessed population (Pasquali, 2013).

\section{Instruments}

The State-Trait Anxiety Inventory - STAI (Spielberg, Gorsuch, Lushene, Biaggio, \& Natalício, 1979) consists of two distinct scales of self-relationship to measure two concepts of anxiety. According to Fioravanti et al. (2006), STAI is one of the most used inventories for assessing anxiety and De souza et al. (2013) points out this instrument as the most appropriate for anxiety assessing in Brazil.

The state-anxiety scale (STAI-S) asks the individual to indicate how he or she feels at the responding moment. The 
trait anxiety scale (STAI-T) asks the individuals to indicate how they generally feel. Each of them is composed of 20 statements, being a Likert-type instrument, separated by 4 response categories: 1. Absolutely not; 2. A little; 3 . Quite and 4. Very much, for STAI-S, and 1. Almost never; 2. Sometimes; 3. Often and 4. Almost always for STAI-T. Individuals respond to each item by evaluating themselves, on a 4-point scale.

\section{Procedures}

To interpret the answers, scores are assigned to each question. At STAI-S the negative questions are: 3, 4, 6, 7, 9, 12, $13,14,17,18$, and the positive questions: 1, 2, 5, 8, 10, 11, 15, 16, 19 , 20. For STAI-T, the negative questions are: 2, 3, 4, 5, $8,9,11,12,14,15,17,18,20$; and positive ones, $1,6,7,10,16,19$. The scores for positive questions are reversed, in these, if the answer is 4, a value of 1 is assigned; if the answer is 3, a value of 2 is assigned, if the answer is 2 a value of 3 is assigned, if the answer is 1 a value of 4 is assigned (Borine, 2011; Spielberger et al., 1983).

In the present study, an evaluation used by Andrade et al. (1994), which classifies trait-state anxiety at 4 levels for the scores obtained: 1 . low (20 to 34 ); 2 . moderate (35 to 49); 3. high (50 to 64); and 4. very high (65 to 80).

The Three Factor Eating Questionnaire- R21 (TFEQ-R21), de Stunkar e Messick (1985), translated and validated in Brazil by Natacci e Ferreira Junior (2011) it consists of 21 questions that assess eating behavior in three dimensions: emotional eating, cognitive restriction and uncontrolled eating. Variables were graded as the author provided classifications, in which from items 1 to 20, it is calculated using a 4-point scale and for question 21, an 8-point numerical scale. The average of each behaviour variables was calculated on a scale from 0 to 100 points, in which the higher the value, the greater the presence of the type of behaviour evaluated. Lima (2012) states a significant association with emotional eating behavior, with diet changes of individuals related with mood changes or challenging situations.

Data were statistically analysed grouping students collectively and never individually. The statistical analysis was inferential (Fávero \& Belfiore, 2017) and means comparison was performed by analysis of variance (ANOVA) performed using the IBM SPSS 25 software (Marôco, 2018).

\section{Results and Discussion}

The prevalence of anxiety (trait and status) stratified by gender, is shown in table 1 . The data on trait anxiety scores (A-trait) showed that $52.9 \%$ of men had a low level of anxiety, while women had a high level of anxiety corresponding to 45.40\%. This data points out that there is a significant difference in anxiety between the female and male population. Regarding the scores of the state anxiety scale (A-state), both genders presented values close to the respective levels. This shows that students, in general, were feeling less anxious than they really are. The results indicated that there was a statistically significant difference between anxiety and gender (A-trait, $p=0.001$ and A-state, $p=0.01$ ).

Table 1: STAI-T and STAI-S scores and gender.

\begin{tabular}{lcccccccc}
\hline & \multicolumn{2}{c}{ Female } & \multicolumn{2}{c}{ Male } & \multicolumn{2}{c}{ STAI-S } & \multicolumn{2}{c}{ Male } \\
& N & \% & N & \% & N & \% & N & \% \\
\hline Low & 17 & 12,1 & 9 & 52,9 & 25 & 17,7 & 5 & 29,4 \\
Moderate & 48 & 34 & 3 & 17,6 & 58 & 41,1 & 9 & 52,9 \\
High & 64 & 45,4 & 4 & 23,5 & 46 & 32,6 & 2 & 11,8 \\
Very High & 12 & 8,5 & 1 & 5,9 & 12 & 8,5 & 1 & 5,9 \\
\hline
\end{tabular}

Source: Authors (2022). 
Regarding the age group of survey participants (Table 2), the A-trace levels for those over 25 years old show that $65 \%$ are classified at a moderate level of anxiety and 35\% at a very high level. In individuals aged 20-25 years, 52\% presented high to very high level, while $48 \%$, low to moderate level. When compared with other ages, a difference was found in individuals up to 19 years of age, in which only $30.8 \%$ showed low level of anxiety, while $69.2 \%$ were at high level. This data, in particular, can portray the pressure experienced by adolescents when entering university, highlighting the transition to adulthood and their new responsibilities in the academic environment.

This indicates that the age group that was most influenced by anxiety at that very moment was of students over 25 years old. And although there is no statistically significant correlation for anxiety and age range, being Idate $\mathrm{E}(\mathrm{p}=0.93$ ) and Idate $\mathrm{T}(\mathrm{p}=0.43)$, differences between ages are present.

Table 2: STAI-T e STAI-S scores and age group.

\begin{tabular}{|c|c|c|c|c|c|c|c|c|c|c|c|c|}
\hline & \multicolumn{4}{|c|}{ STAI-T } & \multicolumn{8}{|c|}{ STAI-S } \\
\hline & \multicolumn{12}{|c|}{ Age group } \\
\hline & \multicolumn{2}{|c|}{$>25$} & \multicolumn{2}{|c|}{$20-25$} & \multicolumn{2}{|c|}{ Up to 19} & \multicolumn{2}{|c|}{$>25$} & \multicolumn{2}{|c|}{$20-25$} & \multicolumn{2}{|c|}{ Up to 19} \\
\hline Low & $\mathrm{N}$ & $\%$ & $\mathrm{~N}$ & $\%$ & $\mathrm{~N}$ & $\%$ & $\mathrm{~N}$ & $\%$ & $\mathrm{~N}$ & $\%$ & $\mathrm{~N}$ & $\%$ \\
\hline Moderate & 6 & 30 & 16 & 12,8 & 4 & 30,8 & 6 & 30 & 22 & 17,6 & 2 & 15,4 \\
\hline High & 7 & 35 & 44 & 35,2 & 0 & 0 & 5 & 25 & 56 & 44,8 & 6 & 46,2 \\
\hline Very High & 5 & 25 & 54 & 43,2 & 9 & 69,2 & 7 & 35 & 37 & 29,6 & 4 & 30,8 \\
\hline Moderate & $2^{\prime}$ & 10 & 11 & 8,8 & 0 & 0 & 2 & 10 & 10 & 8 & 1 & 7,7 \\
\hline
\end{tabular}

Source: Authors (2022).

As shown in Table 3, the relationship between the semester attended and anxiety is more evident in STAI-S scores, which reflects present anxiety. These scores variation in different semesters was significant $(p=0.004)$, with levels of anxiety that can reach up to $80 \%$ from high to very high in the 8th semester, a very concerning fact.

Table 3: STAI-S scores and semester attended.

\begin{tabular}{|c|c|c|c|c|c|c|c|c|c|c|c|c|c|c|c|c|}
\hline \multirow[t]{3}{*}{ STAI-S } & \multicolumn{16}{|c|}{ Semester attended } \\
\hline & \multicolumn{2}{|c|}{$\mathbf{1}^{\mathbf{0}}$} & \multicolumn{2}{|c|}{$2^{\circ}$} & \multicolumn{2}{|c|}{$3^{\mathbf{o}}$} & \multicolumn{2}{|r|}{$4^{\circ}$} & \multicolumn{2}{|c|}{$5^{\circ}$} & \multicolumn{2}{|r|}{$6^{\mathbf{0}}$} & \multicolumn{2}{|c|}{$7^{\circ}$} & \multicolumn{2}{|r|}{$8^{\mathbf{o}}$} \\
\hline & $\mathbf{N}$ & $\%$ & $\mathbf{N}$ & $\%$ & $\mathbf{N}$ & $\%$ & $\mathbf{N}$ & $\%$ & $\mathbf{N}$ & $\%$ & $\mathbf{N}$ & $\%$ & $\mathbf{N}$ & $\%$ & $\mathbf{N}$ & $\%$ \\
\hline Low & 4 & 29 & 1 & 8,3 & 2 & 9,5 & 4 & 50 & 5 & 13,9 & 4 & 21,1 & 10 & 30,3 & 0 & 0 \\
\hline Moderate & 5 & 36 & 6 & 50 & 10 & 48 & 1 & 12,5 & 17 & 47,2 & 7 & 36,8 & 18 & 54,5 & 3 & 20 \\
\hline High & 4 & 29 & 4 & 33 & 8 & 38 & 2 & 25 & 10 & 27,8 & 7 & 36,8 & 5 & 15,2 & 8 & 53,3 \\
\hline Very High & 1 & 7,1 & 1 & 8,3 & 1 & 4,8 & 1 & 12,5 & 4 & 11,1 & 1 & 5,3 & 0 & 0 & 4 & 26,7 \\
\hline
\end{tabular}

Source: Authors (2022).

Analyzing dietary behavior, it is possible to observe a difference between male and female population in the three aspects researched. Due to the small number of male participants compared to female participants in the sample, it is not possible to draw definite conclusions about such difference. However, such disparity between men and women is not a characteristic of the collection, but reflects the actual composition found in the course.

Regarding the age group, it is possible to infer that the only factor with significant variation $F(2,155)=3,34(p<0,05)$ was emotional feeding as can be seen in Figure 1. 
Figure 1: TFEQ-21 scores do and age group.

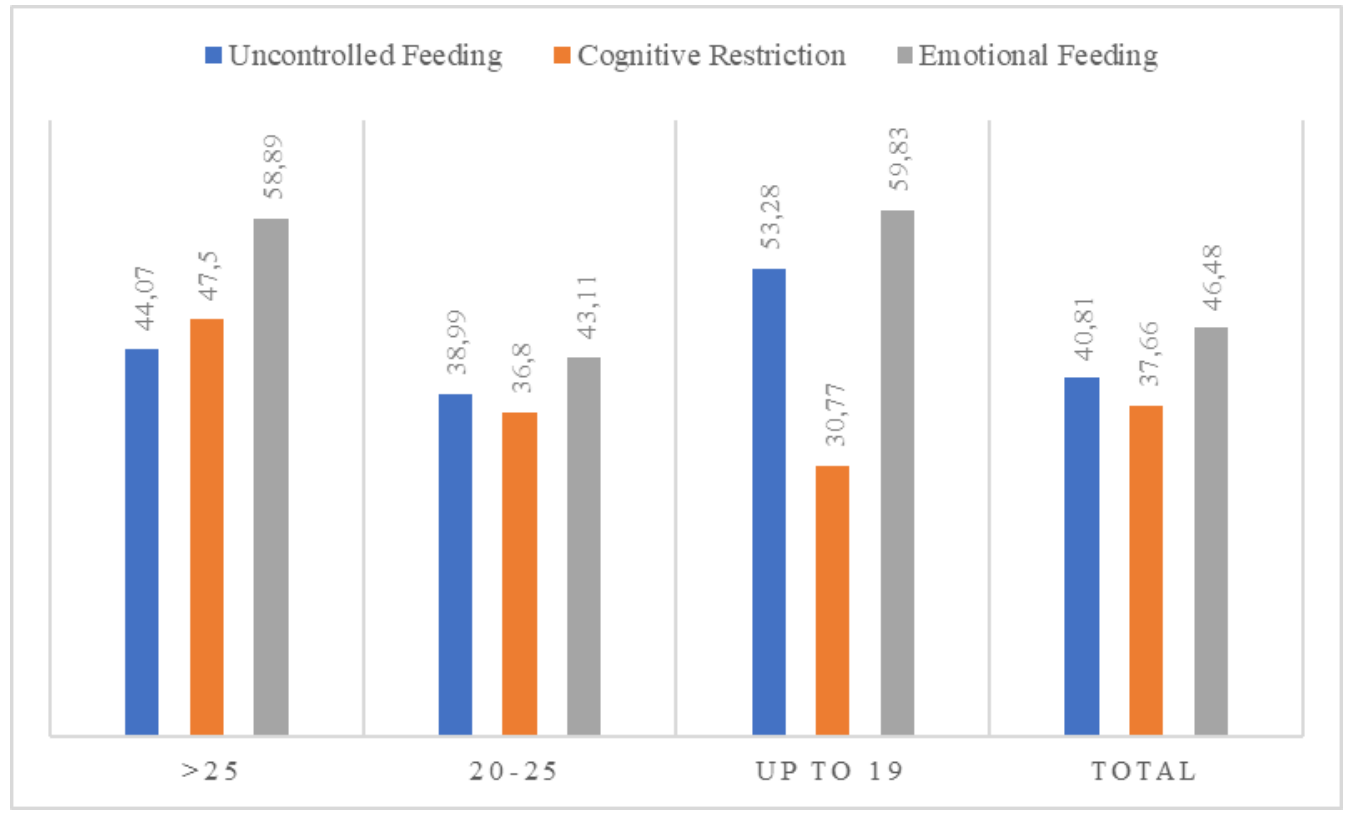

Source: Authors (2022).

According to semester attended (Figure 2), there was a predominance of emotional feeding ( $\mathrm{p}=0.03$ ) and of food uncontrol ( $\mathrm{p}=0.002)$ for the first half of the course, referring to the 1 st to the 4 th period. In relation to the second half, that is, from the 5th to the 8th, the emotional feeding was predominant. It might be possible that as students grows in nutrition literacy during the course, their feeding pattern improves (Liao et al., 2019). These data can be proportional to semester specific demands, taking into account the high burden of responsibility from the moment one is inserted in the academic environment, the increase of contents focused on specific course disciplines and the constant self-judgement regarding grades, these issues can generate internal conflicts, in which eating often becomes an escape.

Figure 2: TFEQ-21scores and semester attended.

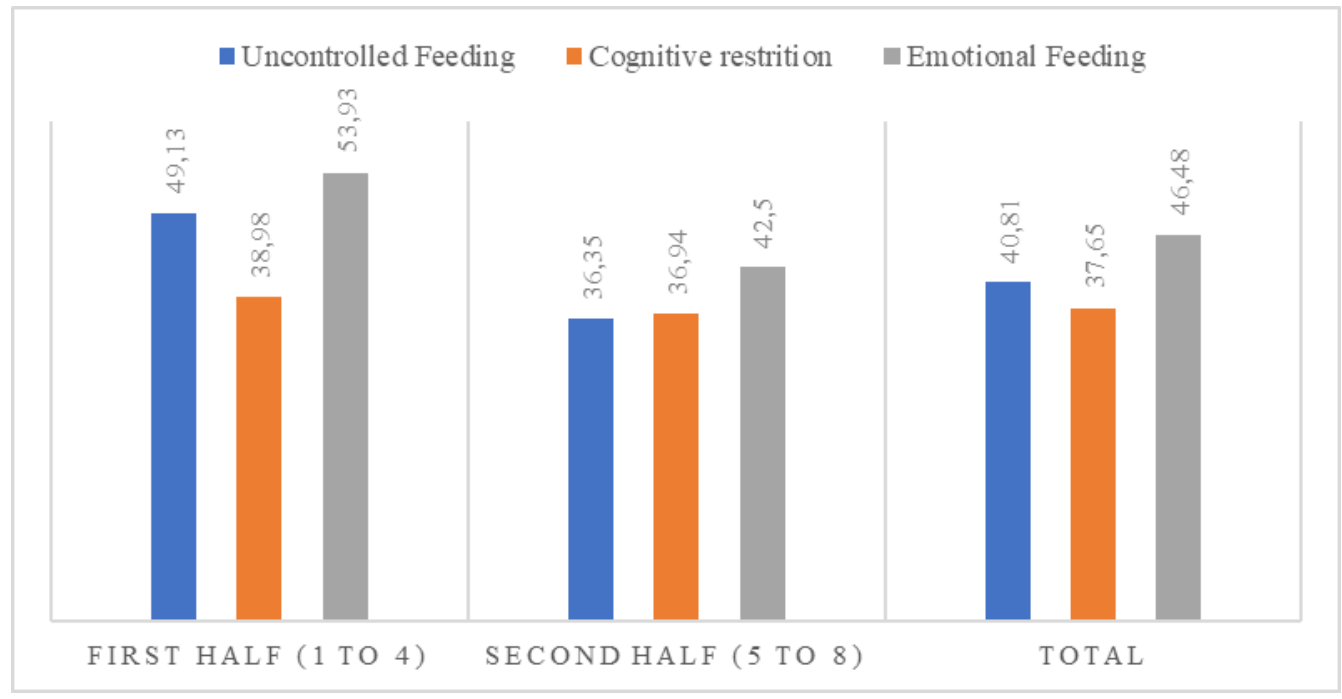

Source: Authors (2022).

For the total sample, positive and significant correlation was observed between level of anxiety through STAI-T and the emotional feeding behavior $(\mathrm{p}=0.000)$. It was also seen a positive correlation between the score of the uncontrolled eating behavior $(\mathrm{p}=0.001)$. For cognitive restriction, there was no correlation $(\mathrm{p}=0.672)$, as shown in table 4 . 
Table 4: Correlation between STAI-T and eating behavior.

\begin{tabular}{lrrr}
\hline Idate T & \multicolumn{3}{c}{ Eating behaviour } \\
& $\begin{array}{c}\text { Uncontrolled } \\
\text { feeding }\end{array}$ & $\begin{array}{c}\text { Cognitive } \\
\text { restrition }\end{array}$ & $\begin{array}{c}\text { Emotional } \\
\text { feeding }\end{array}$ \\
\hline Low & 25,93 & 33,55 & 22,65 \\
Moderate & 38,49 & 39,87 & 43,68 \\
High & 45,59 & 38,07 & 53,35 \\
Very High & 54,7 & 35,04 & 69,23 \\
Low & 40,81 & 37,66 & 46,48 \\
\hline
\end{tabular}

Source: Authors (2022).

Table 5 obtained the same correlation in STAI-S, in emotional feeding behavior $(\mathrm{p}=0.000)$ and uncontrolled feeding $(\mathrm{p}=0.000)$, with results not significant for cognitive restriction $(\mathrm{p}=0.530)$, that is, the relationship is not established in this aspect of food behavior.

Table 5: Correlation between STAI-S scores and eating behavior.

\begin{tabular}{lrrr}
\hline Idate E & \multicolumn{2}{c}{ Eating behaviour } & \\
& $\begin{array}{c}\text { Uncontrolled } \\
\text { feeding }\end{array}$ & Cognitive restrition & $\begin{array}{c}\text { Emotional } \\
\text { feeding }\end{array}$ \\
\hline Low & 27,04 & 32,59 & 32,04 \\
Moderate & 39,64 & 37,73 & 38,31 \\
High & 46,68 & 40,05 & 58,1 \\
Very High & 56,98 & 40,17 & 79,06 \\
Low & 40,81 & 37,66 & 46,48 \\
\hline
\end{tabular}

Source: Authors (2022).

The results showed that anxiety interferes with eating behavior in correlation to uncontrolled eating and emotional feeding, so that as anxiety levels rise, these behaviors evolve together.

The results obtained are compatible with the study by Gama et al. (2008), in which there was a significant difference between genders, showing the female population with higher anxiety scores when compared to the male population. In the study by Lantyer et al. (2016), several health courses were evaluated, including nutrition course. Their results showed that female students had higher levels of anxiety than men, regardless of the area studied and states that women have more susceptibility to develop anxiety.

However, the results of this study confront that of Ferreira et al. (2009b), who stated that the male population, for the first time, was more anxious than women and, like Coelho et al. (2010), in which moderate levels of anxiety were obtained among university students.

In the study conducted by Prado et al (2012) with nursing students, the levels of anxiety found in college students demonstrate high level in their majority, and moderate level respectively, being assimilated with this research.

Data from this research, especially regarding 8th period anxiety level, can collaborate with that of Gondim (2002), who exposed the situation of the current labor market, which requires professionals able to exceed specific technical skills. However, university students, as they approach the end of their education, are faced with a greater concern about professional performance, a feeling that they hold little knowledge, and the fear of leaving the academic environment.

Corroborating the study conducted by Natacci and Ferreira Júnior (2011), the associations of the 3 types of eating 
behavior showed a stronger correlation for emotional feeding and uncontrolled eating. Therefore, no statistically significant associations were found for cognitive restriction behavior.

A positive relationship between emotional feeding and lack of food control was also found in the study by Penaforte, Matta and Japur (2016), who stated that through situations that trigger emotions, it can be difficult to control the amount of food to be eaten. In the same way, the cognitive restriction behavior was not present. As for Souza et al. (2017), who showed little relevant results regarding the significance of cognitive restriction, pointing out that the association is stronger in the other two types of behavior.

In short, the results obtained in this study regarding the types of dietary behavior are in agreement with previous studies in which, among the main changes in dietary behavior, emphasis is placed on emotional feeding and lack of control, rather than cognitive restriction.

\section{Conclusion}

A positive correlation between anxiety and eating behavior was observed in nutrition students, regarding uncontrolled eating and emotional feeding. Considering cognitive restriction, this correlation was not established in the present study.

This correlation may have its origins in the fact that the university student goes through decisive moments such as insertion in the academic environment, his new responsibilities and adaptation and, later, the transition to adult life and performance in the labor market. The pressures and emotions experienced can be difficult to control, making food a way to relieve such feelings.

This aspect is very relevant since, despite all the knowledge and awareness acquired throughout the course regarding food, nutrition and eating behavior, it does not mean that the individual can have control over how to eat. It is evident that the understanding of the proper way to conduct oneself with food is not enough to have the control of behavior, which suffers interference of emotions, and the emotional load should be considered.

This research calls upon the need to promote health care measures for students in order to prevent and minimize the anxiety rates and its consequences in feeding and daily life.

Future researches might expand to other populations to assess how they behave, including health professionals in general, may provide relevant data. In addition, qualitative studies may explain the difference in dietary behavior on cognitive restriction not representing the behavior of these subjects as found in others.

\section{References}

Alvarenga, M., Figueiredo, M., Timerman, F., \& Antonaccio, C. (Eds.). (2015). Nutrição Comportamental. Manole.

Aragão, J. C. S., Casiraghi, B., Mota, É. M., Abrahão, M. A. B., Almeida, T. A. de, Baylão, A. C. do P., \& Araújo, P. A. M. T. (2017). Saúde mental em estudantes de medicina. Revista de Estudios e Investigación en Psicología y Educación, 0(14), 038-041. https://doi.org/10.17979/reipe.2017.0.14.2267

Borine, M. S. (2011). Ansiedade, neuroticismo e suporte familiar: evidência de validade do inventário de ansiedade traço-estado (IDATE). 123.

Brandão, M. L. (2005). As bases biológicas do comportamento: Introdução à neurociência. Revista do Instituto de Medicina Tropical de São Paulo, 47(3), 124-124. https://doi.org/10.1590/S0036-46652005000300013

Castillo, A. R. G., Recondo, R., Asbahr, F. R., \& Manfro, G. G. (2000). Transtornos de ansiedade. Brazilian Journal of Psychiatry, 22, 20-23. https://doi.org/10.1590/S1516-44462000000600006

Chui, H., Bryant, E., Sarabia, C., Maskeen, S., \& Stewart-Knox, B. (2019). Burnout, eating behaviour traits and dietary patterns. British Food Journal, 122(2), 404-413. https://doi.org/10.1108/BFJ-04-2019-0300

Coelho, A. T., Lorenzini, L. M., Suda, E. Y., Rossini, S., \& Reimão, R. (2010). Qualidade de Sono, Depressão e Ansiedade em Universitários dos Últimos Semestres de Cursos da Ârea da Saúde. Neurobiologia, 73, 6.

Corregiari, F. (2012). Ansiedade e medo patológico. In C. G. Mansur (Ed.), Psiquiatria para o Médico Generalista (1a, pp. 152-174). Artmed. 
Cruz, M. C. A., Garcia, T. R., Macedo, R. M., Freitas, Y. J. F. de, Borges, N. M. P., Silva, A. C. S. P. da, Silva, M. L., \& Arruda, J. T. (2021). Influência na qualidade de vida dos estudantes de Medicina relacionadas a má alimentação e sono. Research, Society and Development, 10(2), e23710212393e23710212393. https://doi.org/10.33448/rsd-v10i2.12393

Eisenberg, D., Gollust, S. E., Golberstein, E., \& Hefner, J. L. (2007). Prevalence and correlates of depression, anxiety, and suicidality among university students. American Journal of Orthopsychiatry, 77(4), 534-542. https://doi.org/10.1037/0002-9432.77.4.534

Fávero, L. P., \& Belfiore, P. (2017). Manual de Análise de Dados: Estatística e Modelagem Multivariada com Excel@, SPSS® e Stata®. Elsevier Brasil.

Ferreira, C. L., Almondes, K. M. de, Braga, L. P., Mata, Á. N. de S., Lemos, C. A., \& Maia, E. M. C. (2009a). Universidade, contexto ansiogênico? Avaliação de traço e estado de ansiedade em estudantes do ciclo básico. Ciência \&amp; Saúde Coletiva, 14(3), 973-981. https://doi.org/10.1590/S141381232009000300033

Ferreira, C. L., Almondes, K. M. de, Braga, L. P., Mata, Á. N. de S., Lemos, C. A., \& Maia, E. M. C. (2009b). Universidade, contexto ansiogênico? Avaliação de traço e estado de ansiedade em estudantes do ciclo básico. Ciência \& Saúde Coletiva, 14(3), 973-981. https://doi.org/10.1590/S1413-81232009000300033

Fiates, G. M. R., \& Salles, R. K. de. (2001). Fatores de risco para o desenvolvimento de distúrbios alimentares: Um estudo em universitárias. Revista de Nutrição, 14, 3-6. https://doi.org/10.1590/S1415-52732001000400001

Gama, M. M. A., Moura, G. S., Araújo, R. F., \& Teixeira-Silva, F. (2008). Ansiedade-traço em estudantes universitários de Aracaju (SE). Revista de Psiquiatria Do Rio Grande Do Sul, 30(1), 19-24. https://doi.org/10.1590/S0101-81082008000100007

Gondim, S. M. G. (2002). Perfil profissional e mercado de trabalho: Relação com formação acadêmica pela perspectiva de estudantes universitários. Estudos de Psicologia (Natal), 7(2), 299-309. https://doi.org/10.1590/S1413-294X2002000200011

Kaufman, A. (2013). Alimento e emoção. ComCiência, 145, 0-0. http://comciencia.scielo.br/scielo.php?script=sci_abstract\&pid=S1519$76542013000100012 \& \operatorname{lng}=\mathrm{pt} \& \mathrm{nrm}=\mathrm{iso} \& \operatorname{lng}=\mathrm{pt}$

Kuzujanakis, M. (2020). Anxiety in today's children and young adults. Gifted Education International, 026142942093444. https://doi.org/10.1177/0261429420934445

Lantyer, A. da S., Varanda, C. C., Souza, F. G. de, Padovani, R. da C., \& Viana, M. de B. (2016). Ansiedade e Qualidade de Vida entre Estudantes Universitários Ingressantes: Avaliação e Intervenção. Revista Brasileira de Terapia Comportamental e Cognitiva, 18(2), 4-19. https://doi.org/10.31505/rbtcc.v18i2.880

Liao, L.-L., Lai, I.-J., \& Chang, L.-C. (2019). Nutrition literacy is associated with healthy-eating behaviour among college students in Taiwan. Health Education Journal, 78(7), 756-769. https://doi.org/10.1177/0017896919836132

Lima, L. da S. (2012). Comportamento alimentar e qualidade de vida após 24 meses de cirurgia bariátrica [Dissertação (mestrado), Universidade de Brasília]. https://repositorio.unb.br/handle/10482/13802

Marôco, J. (2018). Análise Estatística com o SPSS Statistics (7th ed.). ReportNumber.

Matos, S. M. R. de, \& Ferreira, J. C. de S. (2021). Estresse e comportamento alimentar. Research, Society and Development, 10(7), e26210716726e26210716726. https://doi.org/10.33448/rsd-v10i7.16726

Natacci, L. C., \& Ferreira Júnior, M. (2011). The three factor eating questionnaire - R21: Tradução para o português e aplicação em mulheres brasileiras. Revista de Nutrição, 24(3), 383-394. https://doi.org/10.1590/S1415-52732011000300002

Pasquali, L. (2013). Psicometria: Teoria dos testes na psicologia e na educação (5a edição). Editora Vozes.

Penaforte, F. R., Matta, N. C., \& Japur, C. C. (2016). Associação entre estresse e comportamento alimentar em estudantes universitários. DEMETRA: Alimentação, Nutrição \& Saúde, 11(1), 225-237. https://doi.org/10.12957/demetra.2016.18592

Prado, J. M. do, Kurebayashi, L. F. S., \& Silva, M. J. P. da. (2012). Eficácia da auriculoterapia na redução de ansiedade em estudantes de enfermagem. Revista da Escola de Enfermagem da USP, 46(5), 1200-1206. https://doi.org/10.1590/S0080-62342012000500023

Souza, M. A. A. de, Gomes, V. C. de S., Silva, E. I. G. e, \& Messias, C. M. B. de O. (2017). Incidência da síndrome do comer noturno e compulsão alimentar em estudantes de Nutrição. Saúde e Pesquisa, 10(1), 15-23. https://doi.org/10.17765/2176-9206.2017v10n1p15-23

Spielberger, C. D., Gorsuch, R. L., \& Lushene, R. (1983). State-trait anxiety inventory STAI (Form Y). Redw City Mind Gard.

World Health Organization. (2017). Depression and other common mental disorders: Global health estimates (Technical Documents WHO/MSD/MER/2017.2). World Health Organization. https://apps.who.int/iris/handle/10665/254610 